\title{
Performa Bobot Badan Akhir, Bobot Karkas serta Persentase Karkas Ayam Merawang pada Keturunan dan Jenis Kelamin yang Berbeda
}

\author{
Nuraini ${ }^{1, *}$, Z. Hidayat ${ }^{1}$, Kiki Yolanda ${ }^{2}$ \\ ${ }^{1}$ BPTP Kepulauan Bangka Belitung, Jl. Mentok Km. 4 Pangkalpinang 33134 \\ ${ }^{2}$ BPTP Yogyakarta, Jl. Stadion Maguwoharjo No.22 Wedomartani, Ngemplak Sleman
}

\begin{abstract}
ABSTRAK
Ayam Merawang merupakan salah satu dari ayam lokal yang berasal dari spesies Gallus-gallus, family Phasianidae. Ayam Merawang merupakan ayam lokal yang berasal dari Desa Merawang Kecamatan Merawang Kabupaten Bangka Propinsi Kepulauan Bangka Belitung dan merupakan sumber genetik serta aset masyarakat Propinsi Kepulauan Bangka. Ayam Merawang sangat potensial untuk dikembangkan sebagai ayam dwiguna penghasil telur dan daging. Penelitian ini dilaksanakan di KP Petaling BPTP Kepulauan Bangka Belitung pada bulan Januari 2017. Tujuan penelitian ini adalah untuk mengetahui performa ayam Merawang keturunan pertama dan kedua baik jantan maupun betina meliputi bobot badan akhir, bobot karkas serta persentase karkas. Materi yang digunakan adalah ayam Merawang sejumlah 24 ekor yang masing-masing 12 ekor untuk keturunan pertama (F1) dan keturunan kedua (F2) serta dibedakan berdasarkan jenis kelamin. Rancangan percobaan yang digunakan menggunakan Rancangan Acak Kelompok Lengkap (RAKL) terdiri dari 2 perlakuan dan 3 ulangan dan satu unit pengamatan sebanyak 2 ekor. Data dianalisis statistika dengan ANOVA dan uji Duncan dengan selang kepercayaan 95\%. Peubah yang diamati pada penelitian ini meliputi bobot badan akhir, bobot karkas serta persentase karkas. Hasil analisis ragam menunjukkan bahwa tidak terdapat perbedaan performa antara ayam Merawang keturunan pertama (F1) dan keturunan kedua (F2). Perbedaan jenis kelamin memberikan pengaruh nyata $(\mathrm{P} \leq 0,05)$ terhadap bobot badan akhir, bobot karkas serta persentase karkas pada ayam Merawang.
\end{abstract}

Kata kunci: Ayam Merawang, Bobot badan akhir, Karkas, Keturunan, Jenis kelamin

\section{Final Body Weight Performance, Weight and Percentage of Carcass of Merawang Chicken in Different Filial and Gender}

\begin{abstract}
Merawang chicken is one of the native chickens from Gallus-gallus species, family Phasianidae. Merawang chicken is a local chicken from Merawang Village, Merawang District, Bangka Regency, Bangka Belitung Islands Province and is a genetic source and community asset of Bangka Island Province. Merawang chicken has the potential to be developed as a dualpurpose chicken producing eggs and meat. The research was conducted at the Petaling trial garden, BPTP Kepulauan Bangka Belitung in January 2017. This study aims to determine the performance of first and second breed Merawang chicken both male and female on the final body weight, carcass weight and carcass percentage. The materials used were 24 Merawang chicken, each of which was 12 for the first breed and the second breed and distinguished by sex. The experimental design used was a Complete Randomized Block Design consisting of 2 treatments and 3 replications and one observation unit as many as 2 heads. Data were analyzed statistically by ANOVA and Duncan test with 95\% confidence interval. The variables observed in this study include the final body weight, carcass weight and carcass percentage. The results of the variance analysis showed that there were no differences in performance between the first breed of Merawang (F1) and the second breed (F2). Sex differences have a significant effect $(P \leq 0.05)$ on the final body weight, carcass weight and percentage of carcass in Merawang chicken.
\end{abstract}

Keywords: Merawang chicken, Final body weight, Carcass, Filial, Sex

\section{PENDAHULUAN}

Salah satu potensi sumber daya genetik peternakan adalah ayam lokal yang diketahui mempunyai variasi genetik cukup tinggi. Ayam lokal merupakan aset yang sangat berharga dalam pembentukan bibit unggul ayam lokal yang terbukti mampu beradaptasi pada lingkungan setempat (Nataamijaya, 2000). Ayam lokal juga merupakan salah satu kekayaan hayati bangsa Indonesia yang telah lama dibudidayakan sehingga mampu beradaptasi dengan lingkungan alam di sekitarnya. Ayam lokal cukup adaptif terhadap iklim tropis dan tahan terhadap pengelolaan dan lingkungan yang buruk serta lebih

\footnotetext{
*Penulis Korespondensi: Nuraini

Alamat: Jl. Mentok Km. 4 Pangkalpinang 33134

E-mail: noenoenk_sky@yahoo.co.id
}

rentan terhadap penyakit. Di Indonesia pemeliharaan ayam lokal sangat mempunyai keuntungan yang lebih besar sebab daya tahan dari penyakit lebih cenderung kebal daripada ayam ras.

Ayam Merawang merupakan salah satu dari ayam lokal tersebut yang berasal dari spesies Gallus-gallus, family Phasianidae (Nataamijaya, 2010). Ayam Merawang merupakan ayam lokal yang berasal dari Desa Merawang Kecamatan Merawang Kabupaten Bangka Propinsi Kepulauan Bangka Belitung dan merupakan sumber genetik serta aset masyarakat Propinsi Kepulauan Bangka Belitung (SK Mentan No. 2846/Kpts./LB.4301812012). Ayam Merawang sangat potensial untuk dikembangkan sebagai ayam dwiguna penghasil telur dan daging (Hasnelly et al., 2006). Pertumbuhan ayam Merawang relatif cepat, berat tubuh ayam jantan dapat mencapai 2-3 kg/ekor pada umur 9- 
12 bulan dan berkisar antara 1,9-3,1 kg/ekor (Ulfah, 2005) sedangkan ayam betina berkisar antara 1,35-2,5 kg/ekor (Armayanti, 2005).

Kondisi yang terkait mengenai masalah utama dalam pengembangan ayam lokal yakni keragaman fenotip dan genetik individu dalam populasi yang semakin tinggi. Zakaria (2004) mengatakan bahwa salah satu faktor rendahnya produktivitas ayam kampung yakni sistem pemeliharaannya yang bersifat tradisional. Demikian juga populasi dan produktivitasnya juga semakin menurun akibat pola perkawinan yang tidak terkontrol dan terkurasnya populasi pada saat-saat upacara keagamaan.

Melihat potensinya sebagai ayam dwiguna penghasil daging sehingga ayam Merawang menjanjikan untuk dikembangbiakkan baik dalam skala kecil maupun komersil sehingga dapat membantu pemenuhan protein hewani serta meningkatkan pendapatan petani. Berdasarkan uraian di atas, penting dilakukan penelitian yang dapat mendukung dan memberikan informasi mengenai performa bobot badan akhir, bobot karkas serta persentase karkas ayam Merawang pada keturunan dan jenis kelamin yang berbeda. Tujuan penelitian ini adalah untuk mengetahui performa ayam Merawang keturunan pertama dan kedua baik jantan maupun betina terhadap bobot badan akhir, bobot karkas serta persentase karkas.

\section{MATERI DAN METODE}

\section{Materi}

Penelitian ini telah dilaksanakan di KP Petaling BPTP Kepulauan Bangka Belitung pada bulan Januari 2017. Penelitian menggunakan ayam Merawang sejumlah 24 ekor yang masing-masing 12 ekor untuk keturunan pertama (F1) dan keturunan kedua (F2) serta dibedakan berdasarkan jenis kelamin. Alat-alat yang digunakan selama penelitian adalah timbangan kapasitas $5 \mathrm{~kg}$, plastik, pisau dan alat tulis.

\section{Pemeliharaan}

Pemeliharaan ayam Merawang dilakukan secara intensif dengan menggunakan sistem kandang battery. Kelompok ayam Merawang yang dipelihara di KP. Petaling didapatkan dari daerah asal ayam Merawang yaitu dari Desa Merawang, Kabupaten Bangka. Pakan yang digunakan selama penelitian yaitu campuran antara dedak : jagung : konsentrat dengan perbandingan $1: 2: 1$ dengan jumlah pemberian \pm 90 g. Pakan diberikan 2 kali sehari yaitu pagi dan sore sedangkan air minum diberikan secara ad libitum.

\section{Pemotongan dan Pengambilan Karkas}

Ayam Merawang sebelum dipotong terlebih dahulu ditimbang untuk mengetahui bobot badan akhir. Sebelum ayam dipotong ayam tidak diberi makan /dipuasakan selama lebih kurang 3 jam, hal ini dilakukan untuk memudahkan pembersihan isi perut. Pemotongan ayam dilakukan dengan metode Kosher yaitu dengan memotong batang tenggorokan (trachea), pembuluh balik leher. (vena jugularis), pembuluh nadi leher (arteri karotis), dan kerongkongan (esophagus) secara bersamaan. Setelah ayam mati, selanjutnya ayam dicelupkan ke dalam air panas dengan suhu 50540C selama 30-50 detik (Soeparno, 2015). Setelah itu, dilakukan pemrosesan yang terdiri atas pencabutan bulu, pemisahan bagian kepala, kaki dan pengeluaran isi jeroan dari termasuk ginjal dan paru-paru dalam tubuh ayam ras petelur jantan. Karkas yang dihasilkan ditimbang dan setelah itu dihitung persentase karkas.

\section{Rancangan Penelitian}

Perlakuan pada penelitian ini terdiri dari 2 kelompok perlakuan. Dua kelompok perlakuan itu yakni ayam Merawang keturunan pertama (F1) dan ayam Merawang keturunan kedua (F2) dan kelompok perlakuan jenis kelamin yaitu ayam Merawang jantan dan ayam Merawang betina. Rancangan percobaan yang digunakan menggunakan Rancangan Acak Kelompok Lengkap (RAKL) terdiri dari 2 perlakuan dan 3 ulangan dan satu unit pengamatan sebanyak 2 ekor.

Peubah yang diamati pada penelitian ini meliputi : 1). bobot badan akhir : bobot akhir ayam sebelum pemotongan; 2). bobot karkas : bobot ayam tanpa darah, bulu, kepala, leher, kaki dan organ dalam serta 3). persentase karkas : bobot karkas dibagi dengan bobot badan akhir dikalikan 100\%. Data dianalisis statistika dengan ANOVA dan uji Duncan dengan selang kepercayaan 95\%. Pengolahan data menggunakan program aplikasi statistika SPSS.

\section{HASIL DAN PEMBAHASAN}

\section{Bobot Badan Akhir Ayam Merawang}

Data rataan bobot badan akhir, bobot karkas dan persentase karkas dapat dilihat pada Tabel 1. Bobot badan akhir adalah bobot yang didapat dengan cara penimbangan bobot ayam hidup pada akhir pemeliharaan (Soeparno, 2015). Bobot akhir bisa diketahui dengan cara penimbangan ayam pada akhir pemeliharaan. Rataan bobot akhir ayam Merawang yang diperoleh selama penelitian disajikan pada Tabel 1. dan hasil analisis ragam menunjukkan bahwa perbedaan antara ayam Merawang keturunan pertama (F1) dan keturunan kedua (F2) memberikan pengaruh berbeda tidak nyata $(\mathrm{P}>0,05)$ tetapi perbedaan jenis kelamin memberikan pengaruh berbeda nyata $(\mathrm{P} \leq 0,05)$ terhadap bobot badan akhir pada ayam Merawang.

Berdasarkan Tabel. 1 dapat dilihat bahwa bobot badan akhir ayam Merawang keturunan pertama (F1) dan keturunan kedua (F2) masing-masing sebesar 1997,9 dan 1773,1 g. Bobot akhir yang tidak berbeda nyata pada ayam Merawang keturunan pertama (F1) dan keturunan kedua (F2) disebabkan karena kualitas pakan yang diberikan selama penelitian sama serta penggunaan kandang battery yang tidak berbeda sehingga bobot akhir ayam tidak berbeda nyata. Hal ini sesuai dengan pendapat Wahju (2015) yang menyatakan bahwa pertumbuhan ternak dipengaruhi 
Tabel 1. Rataan bobot badan akhir, bobot karkas dan persentase karkas ayam Merawang F1 dan F2 jantan dan betina selama penelitian

\begin{tabular}{lccc}
\hline \hline \multicolumn{1}{c}{ Perlakuan } & Bobot Badan Akhir (g) & Bobot Karkas (g) & Persentase Karkas (\%) \\
\hline Keturunan & & \\
F1 & $1997,9^{\mathrm{a}}$ & $1172,83^{\mathrm{a}}$ & $57,93^{\mathrm{a}}$ \\
F2 & $1773,1^{\mathrm{a}}$ & $1074,33^{\mathrm{a}}$ & $60,13^{\mathrm{a}}$ \\
\hline Jenis kelamin & & \\
Jantan & & $1417,08^{\mathrm{a}}$ \\
Betina & $2261,3^{\mathrm{a}}$ & $830,08^{\mathrm{b}}$ & $62,78^{\mathrm{a}}$ \\
\hline CV & $1509,8^{\mathrm{b}}$ & 9,45 & $55,28^{\mathrm{b}}$ \\
\hline Superskrip yang berbeda pada kolom dan faktor yang sama menunjukkan perbedaan yang nyata pada $\mathrm{P}<0,05$. & 6,84
\end{tabular}

oleh faktor bangsa, jenis kelamin, umur, kualitas pakan, dan lingkungannya. Ditambahkan Bell and Weaver (2002) bahwa faktor yang mempengaruhi bobot badan akhir yaitu galur ayam, jenis kelamin, dan faktor lingkungan yang mendukung.

Rataan bobot badan akhir ayam Merawang jantan sebesar 2261,3 g dan betina sebesar 1509,8 g (Tabel 1). Bobot badan akhir dalam penelitian ini sesuai dengan hasil penelitian Ulfah (2005) yang menyebutkan bahwa bobot badan ayam Merawang jantan berkisar antara 1,9-3,1 kg/ekor dan ayam Merawang betina berkisar antara 1,35-2,5 kg/ ekor (Armayanti, 2005) tetapi lebih rendah dibandingkan hasil penelitian Hasnelly dan Armayanti (2005) yang melaporkan bahwa bobot badan ayam Merawang betina dewasa sebesar 1,77 kg.

Ayam Merawang memiliki bobot badan akhir sama dengan ayam lokal lainnya seperti ayam Nunukan jantan sebesar $2.151 \mathrm{~g} /$ ekor dan betina $1.525 \mathrm{~g} /$ ekor (Sartika et a1., 2006) relatif lebih tinggi dibandingkan ayam Wareng yang memiliki bobot hanya sekitar 1007,6 g/ekor untuk jantan dan 841,1 kg/ekor untuk betina (Sartika et al., 2006) dan ayam ketawa jantan dan betina masing-masing sebesar $1,81 \pm 0,08$ dan $1,38 \pm 0,09 \mathrm{~kg}$ (Andrianto et al., 2015). Berdasarkan hasil analisis dapat dilihat bahwa ayam Merawang jantan memberikan pengaruh yang nyata dibandingkan ayam Merawang betina. Bobot badan akhir ayam Merawang jantan pada penelitian ini lebih besar daripada ayam betina karena adanya perbedaan dalam hal hormonal. Pada jantan terdapat sekresi hormon androgen yaitu testosterone yang berpengaruh pada sintesis protein (Sunari, 2001). Pertumbuhan dan bobot badan ayam Merawang yang relatif cepat baik jantan maupun betina sehingga ayam ini potensial dikembangkan sebagai ayam dwiguna. Hal ini sesuai dengan Hasnelly et al. (2006) ayam Merawang sangat potensial dikembangkan sebagai ayam dwiguna penghasil telur dan daging.

\section{Bobot Karkas Ayam Merawang}

Karkas adalah bagian tubuh ayam setelah dilakukan penyembelihan secara halal, pencabutan bulu dan pengeluaran jeroan, tanpa kepala, leher, kaki, paru-paru, dan atau ginjal (SNI, 2009). Rataan bobot karkas ayam Merawang selama penelitian dapat dilihat pada Tabel 1. Dan hasil analisis ragam menunjukkan bahwa perbedaan antara ayam Merawang keturunan pertama (F1) dan keturunan kedua (F2) memberikan pengaruh berbeda tidak nyata $(\mathrm{P}>0,05)$ tetapi perbedaan jenis kelamin memberikan pengaruh berbeda nyata $(\mathrm{P}>0,05)$ terhadap bobot karkas pada ayam Merawang.

Bobot karkas yang berbeda tidak nyata pada ayam Merawang keturunan pertama (F1) dan keturunan kedua (F2) dan berbeda nyata pada ayam Merawang antara jantan dan betina disebabkan bobot akhir yang tidak berbeda nyata antar perlakuan pada ayam Merawang keturunan pertama (F1) dan keturunan kedua (F2) dan berbeda nyata untuk jenis kelamin yang berbeda. Hal ini sesuai dengan pendapat Rasyaf (1998) yang menyatakan bahwa produksi karkas erat hubungannya dengan bobot hidup, semakin bertambah bobot hidup produksi karkas akan semakin bertambah. Didukung pendapat Soeparno (2015) yang menyatakan bahwa semakin tinggi bobot hidup maka produksi karkas semakin meningkat. Peningkatan bobot hidup memiliki hubungan yang erat terhadap bobot karkas.

Rataan bobot karkas ayam Merawang disajikan pada Tabel 1. Menunjukkan bahwa ayam Merawang keturunan pertama (F1) memiliki bobot karkas sebesar 1172,83 g sedangkan ayam Merawang keturunan kedua (F2)memiliki bobot karkas sebesar 1074,33 g sedangkan ayam Merawang jantan dan betina memiliki bobot karkas masing-masing sebesar 1417,08 dan 830,08 g. Bobot karkas pada ayam Merawang selama penelitian selaras dengan bobot badan akhir. Iskandar (2005) menyatakan bahwa bobot karkas dipengaruhi oleh jenis ayam, ransum, bobot hidup, jenis kelamin, dan umur. Bobot karkas dipengaruhi dengan bobot hidup, sehingga bobot hidup yang besar akan diikuti pula oleh bobot karkas yang besar pula, dan sebaliknya. Hal ini sesuai dengan pendapat Wahju (2015) bahwa tingginya bobot karkas ditunjang oleh bobot hidup akhir sebagai akibat pertambahan bobot hidup ternak bersangkutan. Menurut Hayse dan Marion (1973) dalam Resnawati (2004) menyatakan bahwa bobot karkas yang di hasilkan dipengaruhi oleh beberapa faktor yaitu umur, jenis kelamin, bobot potong, besar dan konformasi tubuh, perlemakan, kualitas dan kuantitas ransum serta strain yang dipelihara.

\section{Persentase Karkas Ayam Merawang}

Persentase karkas sering digunakan untuk menilai produksi ternak khususnya produksi daging. Rataan persentase karkas ayam Merawang selama penelitian dapat dilihat pada Tabel 1. Dan hasil analisis ragam 
menunjukkan bahwa perbedaan antara ayam Merawang keturunan pertama (F1) dan keturunan kedua (F2) memberikan pengaruh berbeda tidak nyata $(\mathrm{P}>0,05)$ tetapi perbedaan jenis kelamin memberikan pengaruh berbeda nyata $(\mathrm{P} \leq 0,05)$ terhadap persentase karkas pada ayam Merawang.

Persentase karkas yang berbeda tidak nyata pada ayam Merawang keturunan pertama (F1) dan keturunan kedua (F2) dan berbeda nyata pada ayam Merawang antara jantan dan betina disebabkan bobot akhir yang tidak berbeda nyata antar perlakuan pada ayam Merawang keturunan pertama (F1) dan keturunan kedua (F2) dan berbeda nyata untuk jenis kelamin yang berbeda. Hal ini sejalan dengan pendapat Dewanti et al. (2013) bahwa persentase karkas dipengaruhi oleh bobot potong. Persentase karkas berawal dari laju pertumbuhan yang ditunjukkan dengan adanya pertambahan bobot badan akan mempengaruhi bobot potong yang dihasilkan. Bobot potong akan berpengaruh pada persentase karkas yang dihasilkan. Persentase karkas berhubungan dengan jenis kelamin, umur dan bobot hidup. Jadi persentase karkas meningkat seiring dengan meningkatnya umur dan bobot hidup.

Rataan persentase karkas ayam Merawang disajikan pada Tabel 1. Menunjukkan bahwa ayam Merawang keturunan pertama (F1) memiliki persentase karkas sebesar 57,93\% sedangkan ayam Merawang keturunan kedua (F2) memiliki pesentase karkas sebesar 60,13\% sedangkan ayam Merawang jantan dan betina memiliki pesentase karkas masing-masing sebesar 62,78 dan 55,28\%. Berdasarkan tabel dapat dilihat bahwa persentase karkas ayam Merawang keturunan pertama (F1) lebih tinggi dibanding ayam Merawang keturunan kedua (F2) tetapi tidak memberikan pengaruh yang berbeda nyata $(\mathrm{P}>0,05)$ sedangkan persentase karkas ayam Merawang jantan memberikan pengaruh yang berbeda nyata dibandingkan ayam Merawang betina. Hal ini sesuai dengan Moran (2003) bahwa faktor yang mempengaruhi produksi daging unggas salah satunya adalah jenis kelamin. Persentase karkas ayam Merawang yang digunakan selama penelitian relatif sama dengan yang dilaporkan Balai pembibitan Ternak Unggul (2002) yaitu persentase berat karkas terhadap berat hidup ayam Merawang jantan sebesar 63,58\% dan pada betina $55,27 \%$ tetapi lebih rendah dibandingkan pada ayam Pelung jantan dan betina masing-masing sebesar 65,5 dan $67,4 \%$.

\section{SIMPULAN}

Berdasarkan hasil penelitian dapat disimpulkan bahwa perbedaan performa antara ayam Merawang keturunan pertama (F1) dan keturunan kedua (F2) tidak berbeda tetapi perbedaan jenis kelamin memberikan pengaruh terhadap bobot badan akhir, bobot karkas serta persentase karkas pada ayam Merawang.

\section{DAFTAR PUSTAKA}

Andrianto, L., L. O. Ba'ah, dan M. Rusdin. 2015. SifatSifat Kualitatif dan Kuantitatif Ayam Ketawa di Kota Kendari. Jurnal Ilmu dan Teknologi Peternakan 2(3): 25-35..

Armayanti, R. 2005. Identifikasi Ayam Merawang Betina Sebagai Bibit. Skripsi. Fakultas Petemakan Universitas Padjadjaran. Bandung.

Bell, D. D. and J. R. Weafer. 2002. Commercial Chicken Meat and Egg Production Poultry Specialist. University Of California Riverside. California.

Balai Pembibitan Ternak Unggul. 2002. Performa Ternak di BPTU Sembawa. Balai Pembibitan Ternak Unggul. Direktorat JenderalnBina Produksi Peternakan, departemen Pertanian. Sembawa

Dewanti, R., M. Irham, dan Sudiyono. 2013. Pengaruh Penggunaan Enceng Gondok (Eichornia crassipes) Terfermentasi dalam Ransum terhadap Persentase Karkas, Non-Karkas, dan Lemak Abdominal Itik Lokal Jantan Umur Delapan Minggu. Buletin Peternakan 37(1): 19-25.

Hasnelly, Z. dan R. Armayanti. 2005. Performans Ayam Merawang Betina dewasa Berdasarkan Karakter Kualitatif dan Ukuran-ukuran Tubuh Sebagai Bibit. 2005. lokakarya Nasional. Inovasi Teknologi Dalam Mendukung Usaha Temak Unggas Berdaya Saing. 69-74. Semarang, 4 Agustus 2006.

Hasnelly, Z., Rinaldi dan Suwardih. 2006. Penangkaran dan Perbibitan Ayam Merawang di Bangka Belitung. Lokakarya Nasional. Inovasi Teknologi Dalam Mendukung Usaha Ternak Unggas Berdaya Saing. 7581. Semarang, 4 Agustus 2006.

Hayse, P. L., dan W. W. Merion. 1973. Eviscerated yield components part and broiler. Poultry Science 52: 718- 721.

Iskandar, S. 2005. Pertumbuhan Dan Perkembangan Karkas Ayam Silangan Kedu X Arab Pada Dua Sistem Pemberian Pakan. Jurnal Ilmu Ternak dan Veteriner 10(4): 253-259.

Morran, E. T. 2003. Live production factors influencing yield and quality of poutry meat. In:R.I. Richarson and G.C. Mead (Eds). Poultry meat Science. CABI Publishing, London.

Nataamijaya, A. G. 2010. Pengembangan Potensi Ayam Lokal untuk Menunjang Peningkatan Kesejahteraan Petani. Jurnal Litbang 29 (4): 131138.

Nataamijaya, A. G. 2000. The native chickens of Indonesia. Buletin Plasma Nutfah 6(1): 1-6.

Rasyaf, M. 1998. Memelihara Ayam Kampung. Penebar Swadaya. Jakarta.

Resnawati, H. 2004. Bobot potongan karkas dan lemak abdomen ayam ras pedaging yang diberi ransum mengandung tepung cacing tanah (Lumbricus rubellus). Balai Penelitian Ternak. Bogor.

Sartika, T., S. Sulandari, M. S. A. Zein dan P. Paryanti. 2006. Ayam Nunukan: karakter genetik, fenotipe dan pemanfaatannya. Wartazoa 16: 216-222. 
Sartika, T., S. Iskandar dan S. Sopiyana. 2006. Karakteristik Kualitatif dan ukuranukuran Tubuh Ayam wareng Tangerang. Seminar nasional Teknologi Peternakan dan Veteriner 68: 1-686.

SK Menteri Pertanian No. 2846/Kps/L8.410/812012 tentang penetapan Rumpun Ayam Merawang.

SNI. 2009. Mutu Karkas dan Daging Ayam. Badan Standarisasi Nasional.

Soeparno. 2015. Ilmu dan Teknologi Daging. Cetakan Ke - 6 (Edisi Revisi). Gadjah Mada University Press, Yogyakarta.

Sunari, R. Peni dan S. Wardjosworo. 2001. Persentasi Bagian Pangandan Nonpangan Itik Mandalung pada Berbagai Umur.LokakaryaUnggas Air. Balai Peternakan Ciawi, Bogor

Ulfah, L. 2005. Identifikasi Ayam Merawang Jantan Sebagai Bibit. Skripsi. Fakultas Petemakan Universitas Padjadjaran. Bandung.

Wahju, J. 2015. Ilmu Nutrisi Unggas. Cetakan Ke-6. Gadjah Mada University Press. Yogyakarta.

Zakaria, S. 2004. Pengaruh luas kandang terhadap produksi dan kualitas telur ayam buras yang dipelihara dengan system litter. Buletin Nutrisi dan Makanan Ternak 5(1): 1-11. 